\title{
Psychological Structure of Communication: Scientific and Methodological Aspect
}

\section{Психологічна структура комунікації: науково-методологічний аспект}

\author{
Nataliia Honcharuk \\ Ph.D. in Psychology, Assistant Professor, Kamianets-Podilskyi \\ National Ivan Ohiienko University, Kamianets-Podilskyi (Ukraine) \\ ORCID ID: https://orcid.org/0000-0001-9552-0946 \\ Researcher ID: http://www.researcherid.com/rid/AAC-4110-2019 \\ E-mail: goncharuk.nat17@gmail.com
}

\section{Наталія Гончарук}

Кандидат психологічних наук, доцент, Кам'янець-Подільський національний університет імені Івана Огієнка, м. Кам'янецьПодільський (Україна)

\section{ABSTRACT}

The purpose of the article is to carry out a theoretical and methodological analysis of the psychological structure of communication. According to the purpose, the structural-logical analysis of communication is carried out, its basic components are identified and the psychological model of communication is reproduced.

Methods and techniques. Theoretical and methodological research was carried out on the basis of structural-logical, systematic and differential analysis, comparison, generalization, systematization, and scientific modeling.

Results and discussions. Based on scientific research, the essence of the concept of "communication" is clarified, its most important features and forms

Address for correspondence, e-mail: kpnu_lab_ps@ukr.net Copyright: (C) Honcharuk Nataliia

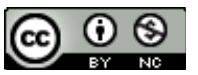


are determined. There are three main components of communication: communicative interaction, communicative behavior, and communicative activity.

By means of scientific analysis, a structural analysis of communicative interaction was carried out, which made it possible to single out its components and the smallest structural elements. The main components are communication and interpersonal relationships. The smallest structural elements are defined as a communicative event, as a holistically realized episode of communication, which involves interactive-informational exchange and communicative situation, as an interconnected set of external and internal factors realized in a particular communicative act.

In addition, the study of communication identified two other components: communicative behavior as a social activity aimed at interaction between individuals, and communicative activity as a social speech activity that has its own meaning and purpose. Communicative behavior is described as an individual set of norms and traditions of communication of individuals within social communities. Communicative activity is reflected as an activity that has an independent communicative purpose and contains all the features of activity such as goal and process setting.

During the theoretical analysis, their smallest structural characteristics were determined. Units of communicative behavior are defined as communicative action and communicative act (interaction), the smallest units of communicative activity - communicative process and communicative action.

Conclusions. On the basis of the conducted structural analysis the most important indicators of communication were described, whose formation became a necessary condition for the formation of communicative skills. A scientific model of communication has been developed and presented in a schematic presentation.

Key words: communication, communicative interaction, communicative behavior, communicative deed, communicative act, communicative activity, communicative process, communicative action.

\section{Introduction}

In the context of increased social urbanization of modern society, communication is an integral part of daily activities. Along with the function of exchanging information between communicators, which is recognized as the most important in

(C) Honcharuk Nataliia

DOI (article): https://doi.org/10.32626/2227-6246.2021-53.78-101 
DOI: https://doi.org/10.32626/2227-6246.2021-53

2021. випуск 53

terms of communicative interaction, its purpose is to ensure socialization among the public, establishing emotional harmony in interpersonal relationships, and mutual support in overcoming critical situations. The presence of such situations often requires psychological help.

Ensuring communication as an object of psychological influence should rely on knowledge of its structure. The analysis of the model of communicative behavior is aimed at understanding the functionality of all components to determine the one that needs correction.

In order to carry out such a structural and functional analysis, researchers have considered various aspects of the structure of communication. A psychological analysis of the levels of construction of communicative actions has been performed (Гончарук \& Онуфрієва, 2018). Its social determinants have been investigated (Горбатюк, 2019; Моісєєва, 2009). Communication in terms of communicative linguistics is described (Горох \& Карпалюк, 2009; Івашкевич \& Примачок, 2020; Макарець, 2021; Семенюк, 2010). Some neuropsychological (Максименко, Ткач, Литвинчук \& Онуфрієва, 2019) and emotional components (Молчанова, 2005) are clarified. However, the issue of coherence of structural elements and their impact on the client's communicative behavior is covered only partially. Insufficient elaboration of the problem in the field of structural analysis allowed to formulate the purpose and objectives of the study.

\section{The task of the article}

The main task of the study is to conduct a theoretical and methodological analysis to determine the psychological structure of communication. Concretization of research tasks makes it possible to identify the following issues: 1) the implementation of scientific analysis of communication; 2) clarification of its main components; 3 ) reproduction and schematic representation of the psychological model of communication.

(C) Honcharuk Nataliia

DOI (article): https://doi.org/10.32626/2227-6246.2021-53.78-101 


\section{Research methods and techniques}

The procedure of theoretical and methodological research involves the use of a set of scientific research methods: structural-logical, systematic and differential analysis, comparison, generalization, systematization, and scientific modeling.

\section{Results and discussions}

Identifying the basic concepts of communication that would help understand the essence of this process, contributes to a deeper understanding of its significance and allows to characterize its impact on interpersonal communication. In psychological research, its most important features are: 1) the availability of information to be transmitted through communication channels; 2 ) the presence of communicative connection between communicators; and 3) the fact of communicative interaction as a means of realization of this connection $(\Gamma \mathrm{OH}-$ чарук \& Онуфрієва, 2018; Онуфрієва, 2020; Поуль \& Бодик, 2019).

The defining component of communication is communicative interaction, which takes the form of an interactive process. In scientific studies, it is described as an act of exchanging information between people or a group of people, necessary for the organization of joint activities, communication, and psychological influence on each other. Interaction includes not only the exchange of actions, but also ideas, interests, moods, feelings and attitudes (Ломов, 2006).

The researcher N.V. Molchanova considers communicative interaction as a system of mutually oriented behavioral reactions that directly affect each other. It acts as a procedural characteristic of communicative interaction: it unfolds in time and space, stimulates the product of interpersonal communication, which comprises emotional and evaluative interpersonal attitudes and information awareness. Thus, communicative interaction as a system of mutually oriented reactions absorbs 
DOI: https://doi.org/10.32626/2227-6246.2021-53

2021. випуск 53

all the complexity of the process of communicative interaction (Молчанова, 2005).

The importance of theoretical and practical study of the problem of communicative interaction, the separation of its main features necessitates a structural-component analysis of this category. Considering the scientific analysis of the product of various forms of communicative interaction, it is possible to determine information awareness and emotional and evaluative attitudes. The first one is the result of communication as an information exchange; the second is a characteristic of productive interpersonal relationships (Онуфрієва, 2020; Ivashkevych \& Onufriieva, 2021).

In the psychology of communication, scholars have always put communication as an informational communicative activity in a prominent place. Communication psychology explores the characteristics of the relationships of communication participants, helps to interact effectively with them and learn more about themselves and the environment. In the scientific interpretation of communication it is a process of information exchange, establishment and development of contacts between people, which is generated by the needs of joint activities and involves the development of a unified strategy of interaction (Кайдалова \& Пляка, 2011). It describes the full range of connections and interactions of people, acting as a way of forming and regulating social relationships.

Along with the concept of communication in scientific studies, there is a category of interpersonal relations (relationships). Communication cannot take place outside the relationship, as it requires at least two people to interact. Therefore, they are a necessary condition for communication, as they provide communicative interaction and are responsible for the effectiveness of communication. At the same time, communication can affect interpersonal relationships: its effectiveness will determine the nature of mutual relations: positive, negative or indifferent.

(C) Honcharuk Nataliia

DOI (article): https://doi.org/10.32626/2227-6246.2021-53.78-101 
From M.M. Horbatiuk's point of view, interpersonal relationships are empirical relationships of real people in their real communication. They describe the direct (or indirectly by technical means) attitude of person to person. Their formation is based on the attitudes and emotional assessments of people towards each other and is the basis of social formation, which is provided through communication with other people (Горбатюк, 2019).

In his study of interpersonal relationships M.M. Horbatiuk distinguishes two types: a) evaluative and b) effective. Evaluators tend to be more passive than active. They establish the importance of mutual actions, their expediency, emotionality, literacy; determine the extent to which the existing communicative behavior affects the achievement of goals. Actors, on the contrary, have an active character and describe the tendency to act proactively, influence various spheres of life and control the course of communication (Горбатюк, 2019).

The analysis suggests that the structure of communicative interaction covers two planes: communication and interpersonal relationships. Communication characterizes the cognitive aspect of communication and is more about information exchange between communicators. Interpersonal relationships outline interpersonal emotional and evaluative attitudes and reflect the emotional side of communication.

In addition to the differential-species classification, a necessary task is to distinguish the structural and component characteristics of communicative interaction. In this context, it is important to describe the communicative event and the communicative situation.

A communicative event is a phenomenon that occurs or does not occur under certain conditions, something important, outstanding, that disrupts the established, normal course of life. In modern science, the event is explained as a media-communicative image of a significant shade of reality outlined in space and time (Рудницька, 2012), a holistic and internally 
connected episode, which has clearly defined boundaries (beginning, end) and is characterized by mandatory cooperation of participants (Рогоза, 2014), the unity of language form, meaning and action, reproduced by the participants of communication, which involves not only language but also the mental processes that accompany the communication process (ШабатСавка, 2012). Examples of communicative events are round tables, workshops, opening ceremonies, presentations. From the point of view of A.P. Rogoza several communicative events form a communicative situation (Рогоза, 2014). This position is somewhat at odds with the views of our study, because we, on the contrary, consider a communicative event as a generic concept in relation to the communicative situation.

At the same time, other investigations indicate that the communicative event and the communicative situation are not hierarchical, but successive categories and represent different aspects of the psychological process. A communicative event is a phenomenon, a real fact of public or private life, and a situation is a set of conditions that affect the communication process (Рудницька, 2012).

The word «situation» means something that happened under certain conditions, situationally. This term is used with the verbs «happened, arose», which confirms its passive state, dependence on certain circumstances. The word «event» comes from the words «after» and "action» - what happened after the action is its consequence. When more often used with an active verb - the event took place.

Thus, the communicative event is a realized fact of communication, which involves the exchange of information and is limited to specific spatio-temporal characteristics. The communicative situation is determined by the conditions that affect the course and outcome of the communicative act.

It is important for our study to analyze the communicative situation in terms of its content. In psychological studies it is considered: a) a combination of living conditions that encourage (C) Honcharuk Nataliia

DOI (article): https://doi.org/10.32626/2227-6246.2021-53.78-101 
DOI: https://doi.org/10.32626/2227-6246.2021-53

2021. випуск 53

communication and the use of speech in communication (Романенко, 2008); b) hierarchically presented component of the discourse, which contains formal-semiotic, cognitive-interpretive and social-interactive components (Семенюк, 2008); c) the situation due to the purpose and objectives of speech communication, which is carried out in accordance with social and cultural norms (Стиліану, 2011).

In our study, the communicative situation is explained as an interconnected set of external and internal factors implemented in a particular communicative act and represented in the communicative behavior of its participants.

Based on the analysis of linguistic characteristics of communication I.S. Semeniuk distinguishes two types of communicative situations: institutional and ritual. The first are related to traditional social institutions and include the following types: a) declarative (appointments, court sentences); b) commissions (guarantees, obligations, consents); c) injunctive (requirements, orders, instructions); d) requisitive (pleas, requests, spells); e) advicive (recommendations, suggestions, advice, invitations). The second, which provides the norms of social relations, is systematized as follows: a) expressive (greetings, thanks, apologies); b) ascertaining (statement, refutation, reminder); c) affirmative (messages, information, testimonies, forecasts) (Семенюк, 2008).

All these situations occur within a certain area of communicative interaction. They cover the area of communication, represented by its social functions and information (thematic) field of discourse.

Thus, the structure of communicative interaction is represented by its forms (communication and interpersonal relationships) and structural units (communicative event and communicative situation).

However, understanding the essence of communication is impossible without determining the content of behavioral and activity characteristics.

(C) Honcharuk Nataliia

DOI (article): https://doi.org/10.32626/2227-6246.2021-53.78-101 
DOI: https://doi.org/10.32626/2227-6246.2021-53

2021. випуск 53

Under the communicative behavior F.A. Moisieieva understands the use of linguistic and extralingual means of communication, the realization of communicative and speech goals and status characteristics of participants in different communication situations (Моiсєєва, 2009).

The researcher I.A. Sternin describes communicative behavior as a set of norms and traditions of communication of individuals within social, age, gender, professional and other groups. According to this definition, the author distinguishes between situational, group and individual norms of communicative behavior. Situational norms of behavior characterize the constraints that are determined by the conditions of the communicative situation, group ones reflect the features of culture for certain groups (professional, gender, social) (Стернін, 2015), individual ones describe the individual culture and experience of the speaker (Макарець, 2021). The boundary between these norms is very mobile and can be violated.

Theoretical analysis indicates that in psychology there are different types of communicative behavior. In particular, they include: persistent, aggressive, passive, passive-aggressive, and manipulative (Trease, 2018). People with persistent communication behave clearly and confidently, control their emotions and respect other people's needs. An aggressive communicator attacks (orally or physically) and believes that all the problems are someone's fault. He who is a representative of passive behavior constantly sends signals of his weakness. Manipulative communicators have a great influence on others and control them for their own benefit (Trease, 2018).

Within the communicative behavior O.V. Dzykovych describes speech behavior. It refers to the communicative-pragmatic aspects of communication, which involve the use of language (language code) in specific circumstances based on the appropriate level of communicative and linguistic competencies (Дзикович, 2015).

(C) Honcharuk Nataliia

DOI (article): https://doi.org/10.32626/2227-6246.2021-53.78-101 
DOI: https://doi.org/10.32626/2227-6246.2021-53

2021. випуск 53

In addition to the linguistic characteristics of communicative behavior, its important components are status-role. In this regard, in the scientific works of M.S. Nevzorova the concept of "communicative mode» is introduced, which defines communicative behavior based on the status and role characteristics of communicators. In view of this, it distinguishes between equal and multi-status communication. Equal-status communication is communication that forms a community in its social status (Невзорова, 2017).

Many studies have described the concept of communicative competence as an important indicator of communicative behavior. It is characterized by a certain level of communicative knowledge, skills and abilities, the degree of communicative qualification required for effective communication with other people. Researchers V.I. Teslenko, S.V. Latin single out the levels of communicative competence, among which are: a) basic, which reflects the reproductive nature of solving communicative tasks; c) optimally adaptive, which is determined by readiness and communicative potential; d) creative search, which allows one to act in problematic situations; e) reflexiveevaluative - the level of independent communicative search (Тесленко \& Латинцев, 2007).

On the basis of theoretical research it is established that the smallest structural characteristics of communicative behavior are a communicative act and a communicative action (action, interaction).

Communicative action focuses on the cultural and moral values of society as a basis for establishing social ties. The researcher in the field of linguistics O.V. Dzykovych identifies a communicative act with a social performative - a statement, a type of message based on a socially significant action ( $\mathrm{I}$ undertake to study well», «I guarantee my support») (Дзикович, 2015).

In contrast to the act, the classic communicative action involves the exchange of verbal actions within the communica-

(C) Honcharuk Nataliia

DOI (article): https://doi.org/10.32626/2227-6246.2021-53.78-101 
DOI: https://doi.org/10.32626/2227-6246.2021-53

2021. випуск 53

tive interaction of the participants of communication. In psychological research, it is seen as an interaction that occurs at a certain place at the intersection of the axes of space and time between the addresser and addressee as carriers of unique psychosociocognitive traits (Горох \& Карпалюк, 2009); interaction of two subjects endowed with the ability to communicate initiative (Ломов, 2006). According to O.A. Semeniuk communicative act is a conceptually and structurally organized exchange of communicative activity within verbal contact, where the subject-sign carrier is a discourse based on a certain situation (Семенюк, 2010).

Summarizing the above, we can state that communicative behavior is a series of communicative acts and actions, social activity focused on interaction between individuals or groups, which is realized in interpersonal relationships, exchange of information, experience, and mutual influence. It is described by speech (verbal and nonverbal communication), status-role (communicative mode) and competence (level of communicative skills) characteristics of communicators.

The smallest structural components of communicative behavior are the communicative act and the communicative act (action, interaction). From the standpoint of our study, a communicative act is a socially motivated act of behavior focused on the cultural and moral values of society. A communicative action is an interaction between the addressee and the addressee, aimed at the implementation of communicative tasks and presented in the form of a purposeful completed action.

In addition to the psychological categories of «communicative interaction" and "communicative behavior», the category of communicative activity is described in scientific research that investigates communication. The terminology «communicative activity», "communicative process» is often used by national researchers. They describe communication as: speech activity that has a structure characteristic of human activity, including the stages of orientation, planning, execution, (C) Honcharuk Nataliia

DOI (article): https://doi.org/10.32626/2227-6246.2021-53.78-101 
and control (Поуль \& Бодик, 2019); communicative activity, which is characterized by intentionality, effectiveness, normativeness and is carried out in the form of language communication (Ніколаєнко \& Ніколаєнко, 2012).

As we can see, communicative activity can be considered as such that has an independent communicative purpose (for example, the formation of communicative knowledge, communicative skills) and contains all the signs of activity (goal-setting, procedural, etc.).

Theoretical analysis of relevant sources shows that some researchers consider communication as a communicative activity. However, it should be noted that in psychology, activity is a type of action that has an independent meaning and purpose. However, in many cases, communication is not the purpose of the activity, but a means of ensuring it. For example, to perform a mathematical problem, one should use speech to analyze the condition of the problem. That is, in this case, the purpose of the activity is to solve a mathematical problem, and its means - speech communication. In view of this, the term «communicative activity» will not be appropriate here. At the same time, there are many situations where it will be appropriate, namely: a) communication as learning (the goal is to learn to communicate); b) communication as a process of socialization (the goal is the acquisition of communication skills for social adaptation in society or a particular group); c) business communication (the goal is the acquisition of knowledge, skills and abilities of business interaction); d) communication as oratory (the goal is the formation of communicative skills), etc.

The main structural components of communicative activity are: its subject, the need for communication, communicative motives, communicative actions, communicative tasks, means and product of communication. At the same time, communicative activity is built as a system of «connected acts», in which it is necessary to distinguish between the positions of the subject-initiator and the subject-partner (Ніколаєнко, 2012).

(C) Honcharuk Nataliia

DOI (article): https://doi.org/10.32626/2227-6246.2021-53.78-101 
Each psychological category includes independent units of different levels. In relation to communicative activity, such structural components are process and action.

A more detailed analysis of the procedural aspect of communication is carried out by E. Josse. According to her position, communication is a double process, which, on the one hand, involves the course of informing, understanding, including the feelings of participants in communication, and on the other - their forms of response. She argues that during communication, procedural communication is carried out from one subject to another and that communication is delivered on the basis of this communication (Josse, 2019).

The researcher L.Ya. Sukhoterin represents the structure of the communicative process in the form of a linear scheme: $\mathrm{M} \rightarrow \mathrm{C} \rightarrow \mathrm{D}$, where $\mathrm{M}$ is monitoring; $\mathrm{C}$ - creative; $\mathrm{D}-$ delivery. In this system, the 1st phase: monitoring (M), from English «To monitor» means to check, control) is observation of communicative behavior (individuals, groups) and tracking their differential trends; Phase 2: creative (C), from English «To create» means to produce) is management of communicative processes with the possibility of influencing the interlocutors and the situation; Phase 3: delivery (D), from English «To deliver" means to deliver feedback) is to receive feedback in the system of communicative activity (Сухотерін, 2007).

Ukrainian researcher O.A. Semeniuk notes that the communicative process, as the most general concept of communication theory, is actualized in the form of communicative actions (Семенюк, 2010). Examples of such actions are greetings, informational messages, thanks, requests, refusals, apologies, and compliments.

According to B.F. Lomov, the process of communicative activity is built as a «system of combined actions». Each action is a relationship of two subjects, two people endowed with the ability to communicate proactively (Ломов, 2006). Therefore, (C) Honcharuk Nataliia

DOI (article): https://doi.org/10.32626/2227-6246.2021-53.78-101 
we see that in scientific research, communicative action is the smallest component of communicative activity, which in an indivisible form represents all the characteristics of a holistic structure.

\section{Conclusions}

Thus, the theoretical analysis of all the above components of the psychological structure of communication gives grounds for the following conclusions.

From the point of view of our research, communication is an interdependent social activity where interlocutors exchange information (cognitive, emotional or other) through special communication channels and participate in communicative interaction. The most important features of communication are the availability of information, communication and communicative interaction as a means of implementing this connection.

According to the results of the scientific analysis, the structure of communication is presented in Figure 1.

Communicative interaction as a component of communication has two main forms: communication, during which information is exchanged and information awareness is formed; and interpersonal relationships, which characterize emotional and evaluative attitudes. Structural analysis of communicative interaction allows to single out its smallest structural elements: a) communicative event is a holistic communicative episode, realized fact of communication, which involves interactive and informational exchange and is limited by specific spatio-temporal characteristics, b) communicative situation is interconnected external and complex factors (conditions of the situation), implemented in a specific communicative act and represented in the communicative behavior of its participants.

Within the framework of communication, communicative behavior and communicative activity are distinguished. Communicative behavior is a behavioral activity of a social nature, aimed at interaction between individuals.

(C) Honcharuk Nataliia

DOI (article): https://doi.org/10.32626/2227-6246.2021-53.78-101 


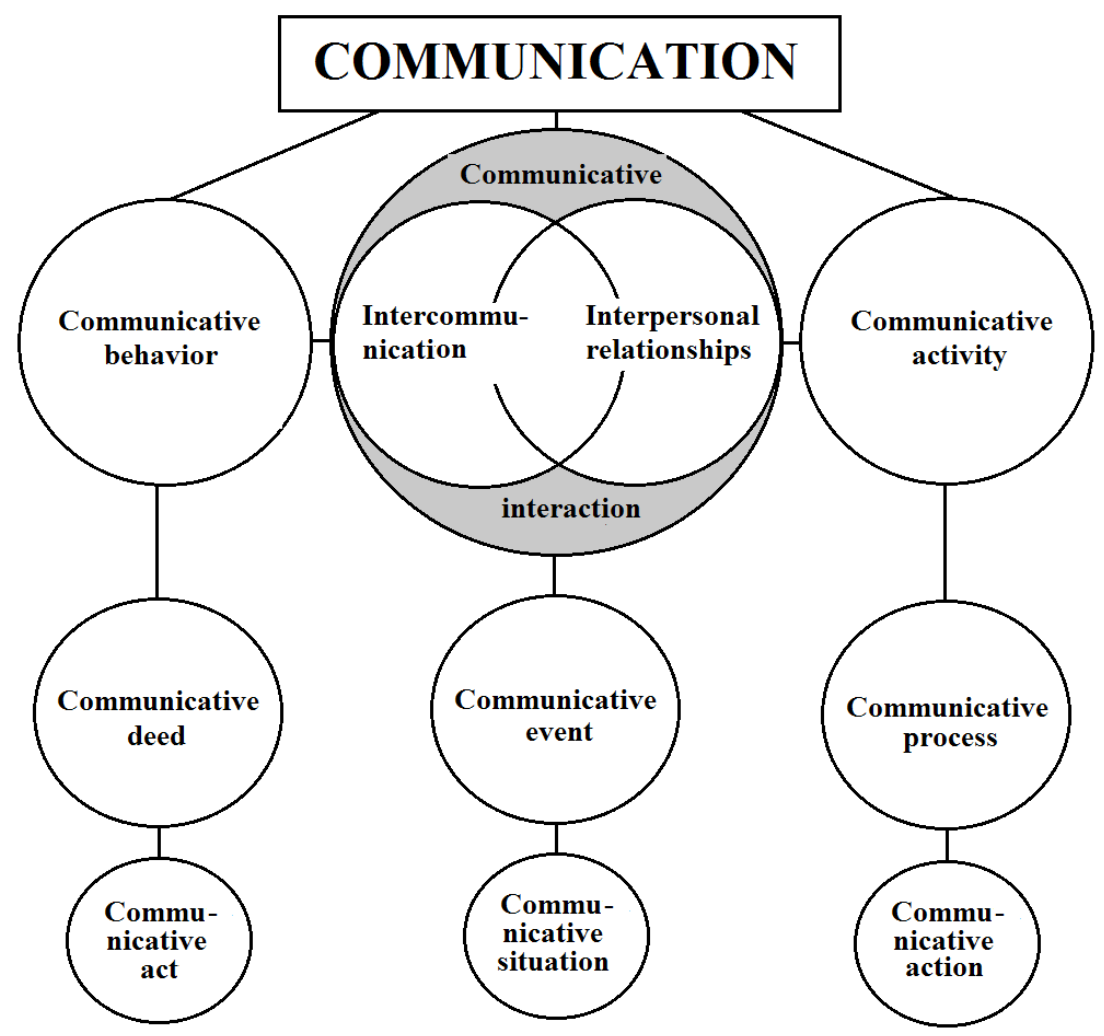

Fig. 1. The structure of interpersonal communication

Its smallest structural characteristics are a communicative deed and a communicative act (interaction). The structural units of communicative activity are the communicative process and communicative action.

The conducted structural analysis allows to identify the integrative interrelation of the most important indicators and criteria of communication, whose formation is a necessary condition for the formation of communicators' individual communicative qualities and ensuring their communicative development.

\section{(C) Honcharuk Nataliia}

DOI (article): https://doi.org/10.32626/2227-6246.2021-53.78-101 


\section{Literature}

Гончарук Н., Онуфрієва Л. Психологічний аналіз рівнів побудови комунікативних дій. Psycholinguistics. Психолінгвістика. Психолингвистика, 2018, 24 (1), 97-117. URL : https://doi.org/10.31470/ 2309-1797-2018-24-1-97-117.

Горбатюк М.М. Міжособистісні стосунки як чинник соціального становлення особистості. Особистісні та ситуативні детермінанти здоров'я: Збірник матеріалів конференції ДНУ імені Василя Стуca. 2019. C. 60-64.

Горох Г.В., Карпалюк В.С. Комунікативна лінгвістика. Кам'янець-Подільський : Зволейко Д.Г., 2009. 283 с.

Дзикович О.В. Комунікативно-прагматичні аспекти мовлення. Київ : НТУУ «КПІ», 2015. 85 c.

Івашкевич Е., Примачок Л. Психолінгвістичні особливості розвитку комунікативної компетентності вчителів загальноосвітніх шкіл. Psycholinguistics. Психолінгвістика. Психолингвистика, 2020, 24 (1), 95-121. URL : https://doi.org/10.31470/2309-1797-202027-1-95-121.

Кайдалова Л.В., Пляка Л.Г. Психологія спілкування. Харків : НФаУ, 2011. 132 c.

Ломов Б.Ф. Психическая регуляция деятельности. Москва : ИП РАН, 2006. $624 \mathrm{c}$.

Макарець Ю. Психолінгвістична природа мовної норми та ï місце серед факторів мовленнєвої діяльності. Psycholinguistics. Психолінгвістика. Психолингвистика, 2021, 29 (2), 151-172. URL : https:// doi.org/10.31470/2309-1797-2021-29-2-151-172.

Максименко С., Ткач Б., Литвинчук Л., Онуфрієва Л. Нейропсихолінгвістичне дослідження політичних гасел із зовнішньої реклами. Psycholinguistics. Психолінгвістика. Психолингвистика, 2019, 26 (1), 246-264. https://doi.org/10.31470/2309-1797-2019-26-1246-264. URL : https://psycholing-journal.com/index.php/journal/ article/view/715.

Моісєєва Ф.А. Комунікативна поведінка в аспекті стосунків між особами. 2009. URL : http://www.rusnauka.com/5_NMIV_2009/Philosophia/40558.doc.htm (дата звернення: 28.05.2021).

Молчанова Н.В. Влияние эмоций на коммуникативное. Кострома, 2005. $24 \mathrm{c}$.

Невзорова М.С. Коммуникативная ситуация устного профессионального общения в рамках англоязычного медицинского дискурса. $\mathrm{Ha}$ учный диалог, 2017, 3, 68-80.

(C) Honcharuk Nataliia

DOI (article): https://doi.org/10.32626/2227-6246.2021-53.78-101 
DOI: https://doi.org/10.32626/2227-6246.2021-53

2021. випуск 53

Ніколаєнко С., Ніколаєнко С. Проблема спілкування як діяльності. Світогляд. Філософія. Релігія: Зб. наук. пр., 2012, 2, 85-93. Суми : УАБС НБУ,

Онуфрієва Л.А. Розвиток професіоналізму майбутніх фахівців соціономічних професій: соціально-психологічний вимір: монографія. Київ : Видавець Бихун В.Ю., 2020. 320 с. ISBN 978-617-7699-08-7.

Поуль В., Бодик О. Вплив регулятивної та планувальної функцій мовлення на вольовий розвиток старших дошкільників і молодших школярів. Psycholinguistics. Психолінгвістика. Психолингвисти$\kappa a, 2019,25$ (1), 256-280. URL : https://doi.org/10.31470/23091797-2019-25-1-256-280.

Рогоза А.П. Мовленнєва системність в термінах комунікативної лінгвістики. Сучасний вилір філологічних наук: Міжнародна науковопрактична конференція. 30-31 травня 2014 року. URL : http:// www.kamts1.kpi.ua/node/1059.

Романенко Т.Л. Моделювання комунікативних ситуацій для формування вмінь іноземного ділового спілкування. Украӥнська наука в лережі Iнтернет: Матеріали Всеукр. науково-практ. інтернетконференції. 2008. URL : http://intkonf.org/category/arhiv/ ukrayinska-nauka-v-merezhi-internet/pedagogika/.

Рудницька Г.В. Факт, подія, новина - взаємозв'язок понять у сучасному журналістикознавстві. Інфорлаційне суспільство, 2012, 15, $13-17$.

Семенюк I.C. Типологія комунікативних ситуацій. Наук. записки ЖдУ ілені Івана Франка: Зб. наук. праць, 2008, 10, 190-194.

Семенюк О.А., Паращук В.Ю. Основи теорії мовної комунікації. Київ : Академія, 2010. 240 с.

Стернин И.А. Модели описания коммуникативного поведения. Воронеж : Гарант, 2015. 52 с.

Стиліану X. I. Комунікативні ситуації як засіб формування культури мовлення старшокласників у процесі вивчення гуманітарних предметів. Зб. наук. праць Хлельницького інституту соиіальних технологій Університету «Україна», 2011, 4, 156-160.

Сухотерин Л.Я., Юдинцев И.В. Информационная работа в государственном аппарате. Москва : Европа, 2007. 480 с.

Тесленко В.И., Латынцев С.В. Коммуникативная компетентность: формирование, развитие, оценивание. Красноярск : КГПУ, 2007. 255 с.

Шабат-Савка С.Т. Дискурс як релевантний спосіб втілення комунікативних інтенцій. Українська лова у XXI столітті: традицї і новаторство: Тези доповідей II Всеукраїнського лінгвістичного форуму молодих учених. Київ, 24-26 квітня 2012 року. С. 451-458.

(C) Honcharuk Nataliia

DOI (article): https://doi.org/10.32626/2227-6246.2021-53.78-101 
Ivashkevych, E., \& Onufriieva, L. The Development of Learner's Autonomy by the Way of the Formation of Social Intelligence. Збірник наукових праць «Проблеми сучасної психологї̈, 2021, 51, 09-32. URL : https://doi.org/10.32626/2227-6246.2021-51.09-32

Josse, E. Les techniques de communication dans la relation d'aide psychologique. Notions de base. Nancy : Pôle universitaire européen de Lorraine, 2019. URL : http://www.resilience-psy.com/spip.php? article 377.

Onufriieva, L.A. The Psychology of Professional Realization of a Future Specialist's Personality: Theoretical and Methodological Aspect. Monograph. Rzeszów : BonusLiber, 2017. 194 s. ISBN 978-83-6544183-6.

Onufriieva, L., Chaikovska, O., Kobets, O., Pavelkiv, R., \& Melnychuk, T. Social Intelligence as a Factor of Volunteer Activities by Future Medical Workers. Journal of History Culture and Art Research, 2020, 9 (1), 84-95. URL : http://dx.doi.org/10.7596/taksad.v9i1.2536.

Trease, Sh.V. Types of communication behavior. Relationships \& family. 2018. URL : https://oureverydaylife.com/types-communicationbehavior-8075513.html.

\section{References}

Honcharuk, N., \& Onufriieva, L. (2018). Psykholohichnyi analiz rivniv pobudovy komunikatyvnykh dii [Psychological analysis of the levels of construction of communicative actions]. Psycholinguistics. Psykholinhvistyka. Psikholingvistika - Psycholinguistics. Psycholinguistics. Psycholinguistics, 24 (1), 97-117. Retrieved from https://doi. 10.31470/2309-1797-2018-24-1-97-117 [in Ukrainian].

Horbatiuk, M.M. (2019). Mizhosobystisni stosunky yak chynnyk sotsialnoho stanovlennia osobystosti [Interpersonal relationships as a factor in the social formation of personality]. Osobystisni ta sytuatyvni determinanty zdorovia: $Z b$. materialiv konferentsii DNU imeni Vasylia Stusa - Personality-based and situational determinants of health: Proceedings of the conference of Vasyl Stus Donetsk National University, (pp. 60-64) [in Ukrainian].

Horokh, H.V., \& Karpaliuk, V.S. (2009). Komunikatyvna linhvistyka [Communicative Linguistics]. Kamianets-Podilskyi : Zvoleiko D.H. [in Ukrainian].

Dzykovych, O.V. (2015). Komunikatyvno-prahmatychni aspekty movlennia [Communicative and pragmatic aspects of speech]. Kyiv : NTUU «KPI» [in Ukrainian].

(C) Honcharuk Nataliia

DOI (article): https://doi.org/10.32626/2227-6246.2021-53.78-101 
DOI: https://doi.org/10.32626/2227-6246.2021-53

2021. ВИПУСК 53

Ivashkevych, E., \& Prymachok, L. (2020). Psykholinhvistychni osoblyvosti rozvytku komunikatyvnoi kompetentnosti vchyteliv zahalnoosvitnikh shkil [Psycholinguistic features of the development of communicative competence of secondary school teachers]. Psycholinguistics. Psykholinhvistyka. Psikholingvistika - Psycholinguistics. Psycholinguistics. Psycholinguistics, 24 (1), 95-121. Retrieved from https:// doi.org/ 10.31470/2309-1797-2020-27-1-95-121 [in Ukrainian].

Kaidalova, L.V., \& Pliaka, L.H. (2011). Psykholohiia spilkuvannia [Psychology of communication]. Kharkiv : NFaU [in Ukrainian].

Lomov, B.F. (2006). Psikhicheskaia reguliatsiia deiatelnosti [Mental regulation of activity]. Moskva : IP RAN [in Russian].

Makarets, Yu. (2021). Psykholinhvistychna pryroda movnoi normy ta yii mistse sered faktoriv movlennievoi diialnosti [Psycholinguistic nature of language norm and its place among factors of speech activity]. Psycholinguistics. Psykholinhvistyka. Psikholingvistika-Psycholinguistics. Psycholinguistics. Psycholinguistics, 29 (2), 151-172. Retrieved from https://doi.org/10.31470/2309-1797-2021-29-2-151172 [in Ukrainian].

Maksymenko, S., Tkach, B., Lytvynchuk, L., \& Onufriieva, L. (2019). Neiropsykholinhvistychne doslidzhennia politychnykh hasel iz zovnishnoi reklamy [A neuropsycholinguistic research of political slogans from outdoor advertising]. Psycholinguistics. Psykholinhvistyka. Psikholingvistika - Psycholinguistics. Psycholinguistics. Psycholinguistics, 26(1),246-264.https://doi.10.31470/2309-1797-2019-26-1-246-264. Retrieved from https://psycholing-journal.com/index.php/journal/ article/view/715 [in Ukrainian].

Moisieieva, F.A. (2009). Komunikatyvna povedinka $v$ aspekti stosunkiv mizh osobamy [Communicative behavior in the aspect of interpersonal relationships]. Retrieved from http://www.rusnauka.com/5_NMIV 2009/Philosophia/40558.doc.htm (data zvernennia: 21.04.2020) [in Ukrainian].

Molchanova, N.V. (2005). Vliianiie emotsii na kommunikativnoie vzaimodeistviie [The influence of emotions on the communicative unit]. Kostroma [in Russian].

Nevzorova, M.S. (2017). Kommunikativnaia situatsiia ustnogo professionalnogo obshcheniia $\mathrm{v}$ ramkakh angloiazychnogo meditsinskogo diskursa [Communicative situation of oral professional communication within the framework of English-language medical discourse]. Nauchnyi dialog - Scientific dialogue, 3, 68-80 [in Russian].

Nikolaienko, S., \& Nikolaienko, S. (2012). Problema spilkuvannia yak diialnosti [The problem of communication as an activity]. Svitohliad.

(C) Honcharuk Nataliia

DOI (article): https://doi.org/10.32626/2227-6246.2021-53.78-101 
DOI: https://doi.org/10.32626/2227-6246.2021-53 2021. ВИПУСК 53

Filosofiia. Relihiia - Outlook. Philosophy. Religion, 2, 85-93. Sumy : UABS NBU [in Ukrainian].

Onufriieva, L.A. (2020). Rozvytok profesionalizmu maibutnikh fakhivtsiv sotsionomichnykh profesii: sotsialno-psykholohichnyi vymir [The development of the professionalism of future specialists of socionomic professions: socio-psychological aspect]. Kyiv: Publisher Bykhun V.Yu. ISBN 978-617-7699-08-7 [in Ukrainian].

Poul, V., \& Bodyk, O. (2019). Vplyv rehuliatyvnoi ta planuvalnoi funktsii movlennia na voliovyi rozvytok starshykh doshkilnykiv i molodshykh shkoliariv [Influence of regulatory and planning functions of speech on volitional development of senior preschoolers and junior schoolchildren]. Psycholinguistics. Psykholinhvistyka. Psikholingvistika - Psycholinguistics. Psycholinguistics. Psycholinguistics, 25 (1), 256-280. Retrieved from https://doi.org/10.31470/2309-17972019-25-1-256-280 [in Ukrainian].

Rohoza, A.P. (2014). Movlennieva systemnist v terminakh komunikatyvnoi linhvistyky [Speech system in terms of communicative linguistics]. Suchasnyi vymir filolohichnykh nauk - Modern dimension of philological sciences: Proceedings of International scientific and practical conference. Retrieved from http://www.kamts1.kpi.ua/node/ 1059 [in Ukrainian].

Romanenko, T.L. (2008). Modeliuvannia komunikatyvnykh sytuatsii dlia formuvannia vmin inozemnoho dilovoho spilkuvannia [Modeling of communicative situations for the formation of foreign business communication skills]. Ukrainska nauka $v$ merezhi Internet - Ukrainian science in the Internet: Proceedings of all-Ukrainian scientific and practical Internet conferences. Retrieved from http://intkonf.org/ category/arhiv/ukrayinska-nauka-v-merezhi-internet/pedagogika/ [in Ukrainian].

Rudnytska, H.V. (2012). Fakt, podiia, novyna - vzaiemozviazok poniat u suchasnomu zhurnalistykoznavstvi [Fact, event, news - the relationship of concepts in modern journalism]. Informatsiine suspilstvo Information society, 15, 13-17 [in Ukrainian].

Semeniuk, I.S. (2008). Typolohiia komunikatyvnykh sytuatsii [Typology of communicative situations]. Naukovi zapysky ZhDU imeni Ivana Franka - Scientific Notes of Ivan Franko State University, 10, 190194 [in Ukrainian].

Semeniuk, O.A., \& Parashchuk, V.Yu. (2010). Osnovy teorii movnoi komunikatsii [Fundamentals of the theory of language communication]. Kyiv : Akademia [in Ukrainian].

(c) Honcharuk Nataliia

DOI (article): https://doi.org/10.32626/2227-6246.2021-53.78-101 
DOI: https://doi.org/10.32626/2227-6246.2021-53

2021. виПуск 53

Sternin, I.A. (2015). Modeli opisaniia kommunikativnogo povedeniia [Models for describing communicative behavior]. Voronezh : Garant [in Russian].

Stylianu, Kh.I. (2011). Komunikatyvni sytuatsii yak zasib formuvannia kultury movlennia starshoklasnykiv u protsesi vyvchennia humanitarnykh predmetiv [Communicative situations as a means of forming the speech culture of high school students in the study of humanities]. Zbirnyk naukovykh prats KhIST Universytetu «Ukraina»Collection of research papers of KhIST of the University «Ukraine», 4, 156-160 [in Ukrainian].

Sukhoterin, L.Ya., \& Yudintsev, I.V. (2007). Informatsionnaia rabota $v$ gosudarstvennom apparate [Information work in the state apparatus]. Moskva : Evropa [in Russian].

Teslenko, V.I., \& Latyntsev, S.V. (2007). Kommunikativnaia kompetentnost: formirovaniie, razvitiie, otsenivaniie [Communicative competence: formation, development, assessment]. Krasnoiarsk : KGPU [in Russian].

Shabat-Savka, S.T. (2012). Dyskurs yak relevantnyi sposib vtilennia komunikatyvnykh intentsii [Discourse as a relevant way of embodying communicative intentions]. Ukrainska mova u XXI stolitti: tradytsii $i$ novatorstvo - Ukrainian language in the XXI century: traditions and innovation: Proceedings from all-Ukrainian linguistic forum of young researches, (pp. 451-458). Kyiv [in Ukrainian].

Ivashkevych, E., \& Onufriieva, L. (2021). The Development of Learner's Autonomy by the Way of the Formation of Social Intelligence. Zbirnyk naukovykh prats «Problemy suchasnoi psykholohii»-Collection of research papers "Problems of modern Psychology», 51, 09-32. Retrieved from https://doi.org/10.32626/2227-6246.2021-51.09-32.

Josse, E. (2019). Les techniques de communication dans la relation d'aide psychologique [Communication techniques in the counseling relationship]. Notions de base - Basics. Nancy : Pôle universitaire européen de Lorraine. Retrieved from http://www.resilience-psy.com/ spip.php?article377 [in French].

Onufriieva, L.A. (2017). The Psychology of Professional Realization of a Future Specialist's Personality: Theoretical and Methodological Aspect. Rzeszów : BonusLiber. ISBN 978-83-65441-83-6.

Onufriieva, L., Chaikovska, O., Kobets, O., Pavelkiv, R., \& Melnychuk, T. (2020). Social Intelligence as a Factor of Volunteer Activities by Future Medical Workers. Journal of History Culture and Art Research, 9 (1), 84-95. Retrieved from http://dx.doi.org/10.7596/ taksad.v9i1.2536.

(C) Honcharuk Nataliia

DOI (article): https://doi.org/10.32626/2227-6246.2021-53.78-101 
DOI: https://doi.org/10.32626/2227-6246.2021-53

2021. ВИПУСК 53

Trease, Sh.V. (2018). Types of communication behavior. Relationships \& family. Retrieved from https://oureverydaylife.com/types-communication-behavior-8075513.html.

Гончарук Наталія. Психологічна структура комунікації: науково-методологічний аспект

\section{АНОТАЦІЯ}

Mema cmammi - здійснити теоретико-методологічний аналіз психологічної структури комунікації. На основі мети проведено структурно-логічний аналіз комунікації, виокремлено основні ії складові та відтворено психологічну модель комунікації.

Методи та методики дослідження. Теоретико-методологічне дослідження здійснено на основі структурно-логічного, системного та диференційного аналізу, порівняння, узагальнення, систематизації, наукового моделювання.

Результати та дискусії. На основі наукового дослідження з'ясовано сутність поняття "комунікація», визначено найважливіші ї̈ ознаки та форми. Виокремлено три основні складові комунікації: комунікативну взаємодію, комунікативну поведінку, комунікативну діяльність.

Шляхом наукового аналізу здійснено структурний аналіз комунікативної взаємодії, що дав змогу виокремити ії компоненти і найменші структурні елементи. До основних складових віднесено спілкування та міжособистісні стосунки. Найменшими структурними елементами визначено комунікативну подію як иілісний реалізований епізод комунікації, що передбачає інтерактивно-інформаційний взаємообмін і комунікативну ситуацію як взаємопов'язаний комплекс зовнішніх і внутрішніх чинників, реалізованих у конкретному комунікативному акті.

Окрім цього, у межах дослідження комунікації виокремлено ще два компоненти: комунікативну поведінку як активність соціального характеру, спрямовану на взаємодію між окремими особами, та комунікативну діяльність як соціально-мовленнєву активність, яка має самостійний сенс і мету. Комунікативну поведінку описано як індивідуальну сукупність норм і традицій спілкування окремих особистостей у межах соціальних спільнот. Комунікативну діяльність відображено як активність, що має самостійну комунікативну мету й містить усі ознаки діяльності, такі як цілепокладання та процесуальність.

(C) Honcharuk Nataliia

DOI (article): https://doi.org/10.32626/2227-6246.2021-53.78-101 
DOI: https://doi.org/10.32626/2227-6246.2021-53

2021. випуск 53

Під час теоретичного аналізу визначено найменші структурні характеристики. Одиницями комунікативної поведінки означено комунікативний вчинок і комунікативний акт (інтеракцію), найменшими одиницями комунікативної діяльності - комунікативний процес і комунікативну дію.

Висновки. На основі проведеного структурного аналізу описано найважливіші показники комунікації, формування яких стало необхідною умовою становлення комунікативних умінь і навичок. Розроблено наукову модель комунікації, представлену в схематичній презентації.

Ключові слова: комунікація, комунікативна взаємодія, комунікативна поведінка, комунікативний вчинок, комунікативний акт, комунікативна діяльність, комунікативний процес, комунікативна дія.

\section{Гончарук Наталия. Психологическая структура коммуникации: научно- методологический аспект}

\section{АННОТАЦИЯ}

Цель статьи - провести теоретико-методологический анализ психологической структуры коммуникации. На основе цели осуществлен структурно-логический анализ коммуникации, выделены основные ее составляющие и воспроизведена психологическая модель коммуникации.

Методы и методики исследования. Теоретико-методологическое исследование осуществлялось на основе структурно-логического, системного и дирфреренциального анализа, сравнения, обобщения, систематизации, научного моделирования.

Результаты и дискуссии. На основе научного исследования изучена сущность понятия "коммуникация», определены важнейшие ее признаки и формы. Выделены три основных составляющих коммуникации: коммуникативное взаимодействие, коммуникативное поведение, коммуникативная деятельность.

Путем научного анализа осуществлен структурный анализ коммуникативного взаимодействия, который позволил выделить его компоненты и наименьшие структурные элементы. К компонентам относятся общение и межличностные отношения. Наименьшими структурными элементами определены: а) коммуникативное событие как целостный реализованный во времени эпизод коммуникации, который предусматривает интерактивно-информационный взаимообмен; б) коммуника(C) Honcharuk Nataliia

DOI (article): https://doi.org/10.32626/2227-6246.2021-53.78-101 
DOI: https://doi.org/10.32626/2227-6246.2021-53

2021. випУСК 53

тивная ситуация как взаимосвязанный комплекс внешних и внутренних факторов, реализованных в конкретном коммуникативном акте.

Кроме того, в рамках исследования коммуникации выделены еще два компонента: коммуникативное поведение как активность социального характера, направленная на взаимодействие между отдельными лицами, и коммуникативная деятельность как социально-речевая активность, имеющая самостоятельный смысл и цель. Коммуникативное поведение описано как индивидуальная совокупность норм и традиций общения отдельных личностей в рамках социальных сообществ. Коммуникативная деятельность отражена как активность, имеющая самостоятельную коммуникативную цель и содержащая все признаки деятельности, такие как целеполагание и процессуальность.

Во время теоретического анализа определены наименьшие структурные характеристики. Единицами коммуникативного поведения отмечены коммуникативный поступок и коммуникативный акт (интеракция), наименьшими единицами коммуникативной деятельности - коммуникативный процесс и коммуникативное действие.

Выводы. На основе проведенного структурного анализа описаны важнейшие показатели коммуникации, формирование которых стало необходимым условием становления коммуникативных умений и навыков. Разработана научная модель коммуникации, представленная в схематической презентации.

Ключевые слова: коммуникация, коммуникативное взаимодействие, коммуникативное поведение, коммуникативный поступок, коммуникативный акт, коммуникативная деятельность, коммуникативный процесс, коммуникативное действие.

Original manuscript received April 27, 2021

Revised manuscript accepted June 05, 2021 